Article available at nttp://www.parasite-journal.org or nttp://dx.dol.org/10.1051/parasite/200108s2223

\title{
REDUCTION OF MUSCLE LARVAE BURDEN IN RATS EXPERIMENTALLY INFECTED WITH TRICHINELLA SPIRALIS
}

\author{
MACHNICKA-ROWIŃSKA B.* \& DZIEMIAN E.*
}

\section{Summary :}

In Wistar rats infected with 500 to 2,500 Trichinella spiralis larvae the muscle larvae intensity (larvae per gram-l.p.g.) was measured from 20 to 180 day post infection (d.p.i). The I.p.g. increased to day 40-50 p.i. and decreased thereafter. The highest reduction took place between 60 and 120 d.p.i. with intermediate inoculum of $T$. spiralis larvae. The mechanism of the reduction of $T$. spiralis larvae in muscles is suggested to depend on pericapsular-intercapsular host cells infiltrations attracted by parasite antigens.

KEY WORDS : trichinellosis, larvae, muscles, reduction, rats.

I nfection with T. spiralis results in the long-lasting survival of larvae in the striated muscles of many mammals. The information on the proportion of larvae which survive in relation to these deriving from infection is lacking. In order study the fate of larvae in rats experimentally infected with different doses, we examined samples of Musculus gastrocnemius. The studies were performed until 180 d.p.i. The following data were determined: period of the highest burden of larvae in the muscles, the influence of the infective dose on the number of secondary larvae and the dimentions of their reduction.

\section{MATERIALS AND METHODS}

T nbred Wistar rats, males aged 10-12 weeks and weighing 120-140 g at the beginning of experiments, kept at conventional conditions, were infected with T. spiralis larvae (s. str.) maintained in rats. All muscle tissue were examined by digestion ( $1 \%$ pepsin $+1 \%$ $\mathrm{HCl})$. The rats infected with $500,1,200$ and 2,500 T. spiralis larvae were examined from day 20 to day 60 p.i. every 10-th day and then 90, 120 and 180 d.p.i. The rats infected with 700, 1,000 and 1,900 T. spiralis larvae were examined 60 and 180 d.p.i.

* Institute of Parasitology of the Polish Academy of Sciences, 00-818 Warsaw, 51/55 Twarda str, Poland.
Mean larval burdens were compared statistically by the Student's t-test.

\section{RESULTS}

1 The first $T$. spiralis larvae in $M$. gastrocnemius were observed 20 d.p.i. The l.p.g. increased up to day 40-50 p.i. in rats infected with 500, 1,200 and 2,500 larvae (Figs 1, 2, 3). Between days 50 and 180 p.i., there was a significant reduction. As it is demonstrated in Figure 4, a similar reduction was observed in rats infected with 700, 1,000 and 1,900 T. spiralis larvae and which were examined 60 and 180 d.p.i. The highest reduction, (over $70 \%$ ) was observed in rats infected with intermediate numbers of larvae: $1,000,1,200$ and 1,900 (Fig. 5). Infection with smaller or higher numbers of larvae resulted in a less important reduction (from 47 to $68 \%$ ).

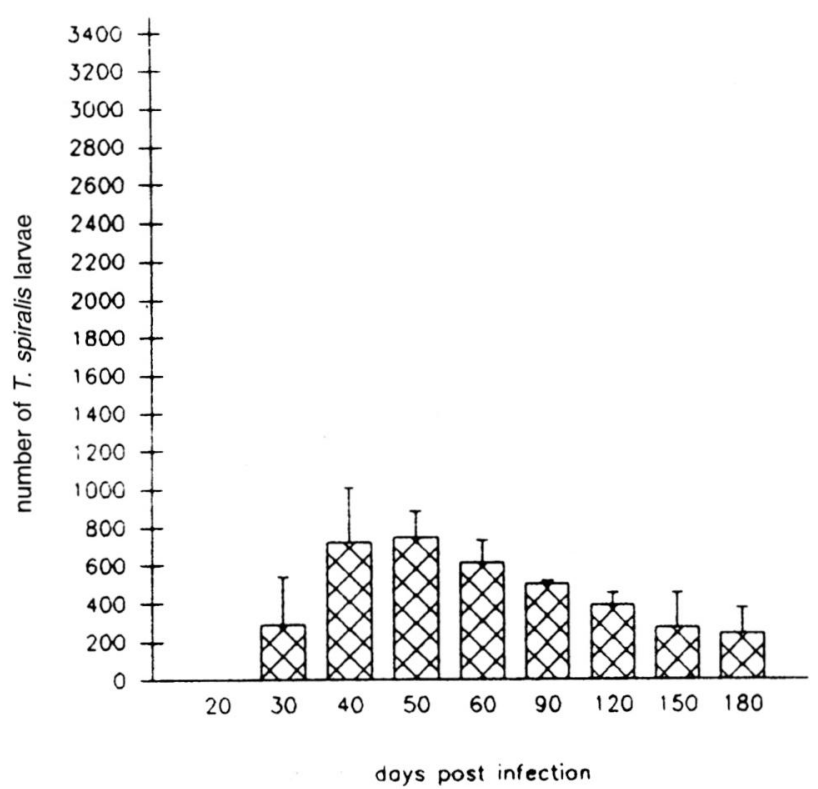

Fig. 1. - Number of Trichinella spiralis larvae per $1 \mathrm{~g}$ of Musculus gastrocnemius in rats infected with 500 larvae. Three animals were examined for each experiment $(n=3)$.

* significant differences. 


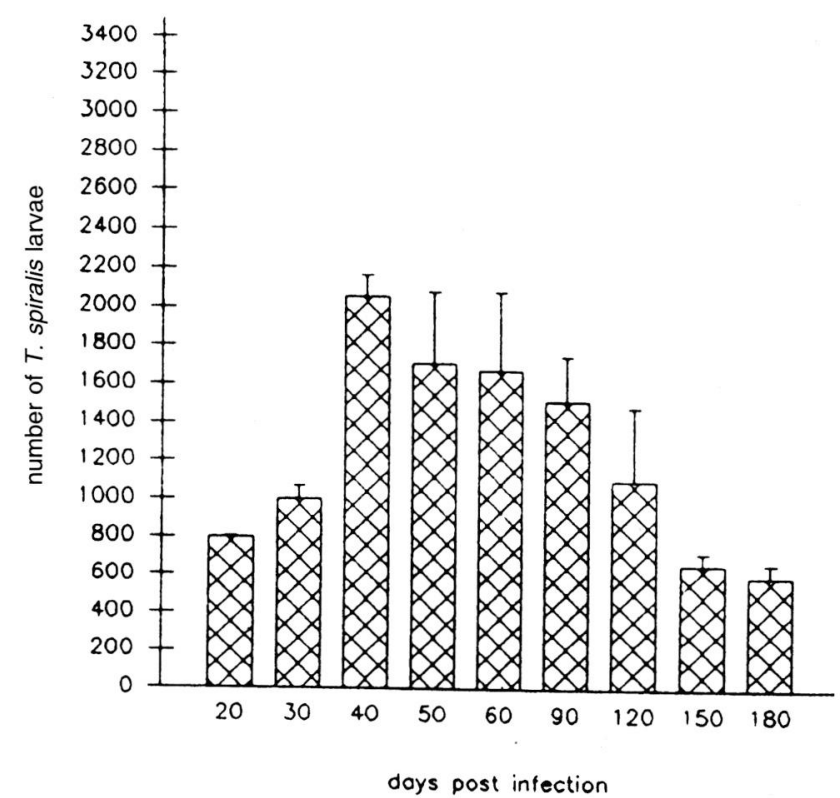

Fig. 2. - Number of Trichinella spiralis larvae per $1 \mathrm{~g}$ of Musculus gastrocnemius in rats infected with 1,200 larvae. Seven animals were examined for each experiment $(n=7)$.

* significant differences.

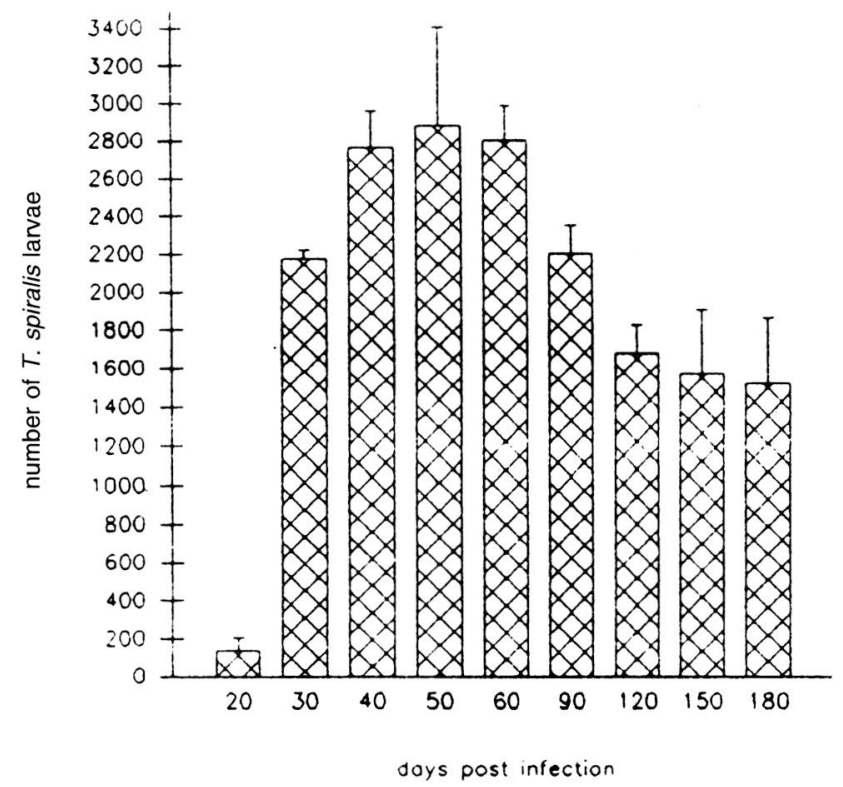

Fig. 3. - Number of Trichinella spiralis larvae per $1 \mathrm{~g}$ of Musculus gastrocnemius in rats infected with 2,500 larvae. Three animals were examined for each experiment $(\mathrm{n}=3)$.

* significant differences.

\section{DISCUSSION}

The examination in rats pointed out that diverse infective doses of $T$. spiralis larvae resulted in different numbers of secondary larvae per $1 \mathrm{~g}$

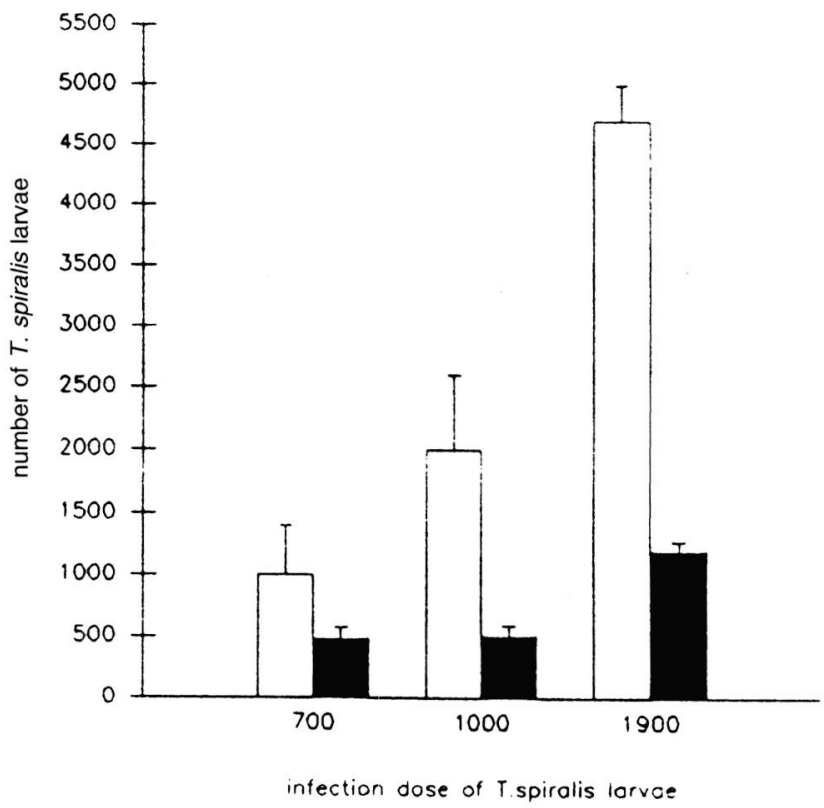

Fig. 4. - Number of Trichinella spiralis larvae per $1 \mathrm{~g}$ of Musculus gastrocnemius in rats infected with $700(n=20), 1,000(n=20)$ and 1,900 (n = 15) larvae detected 60 d.p.i. $\square$ and 180 d.p.i.

* significant differences.

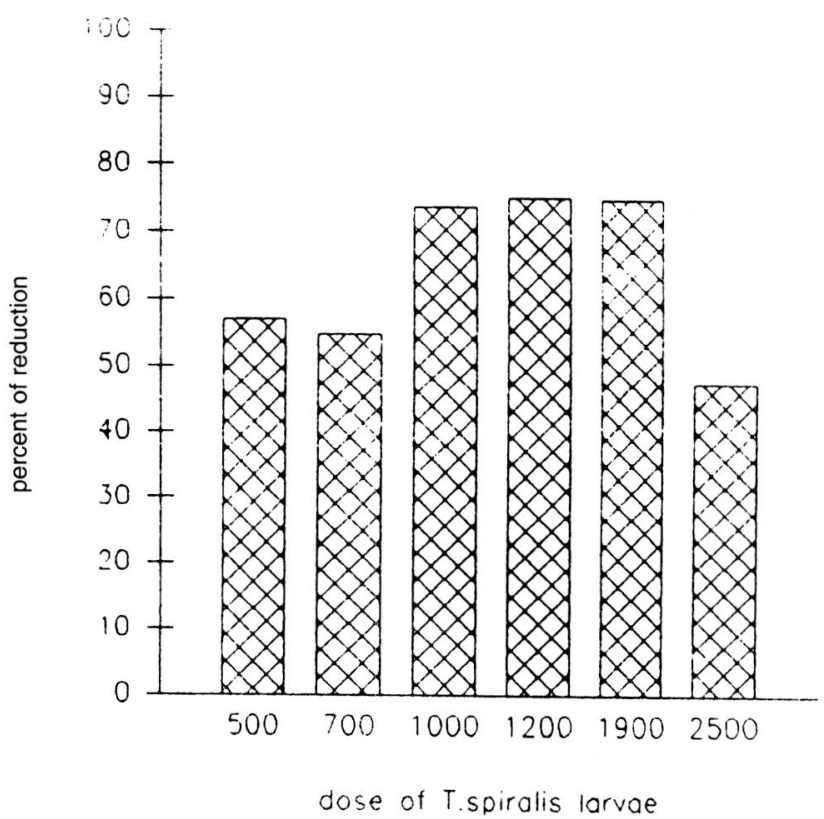

Fig. 5. - Percent of reduction of Trichinella spiralis larvae between 60 d.p.i. and 180 d.p.i. per $1 \mathrm{~g}$ of Musculus gastrocnemius of rats infected with different doses of Trichinella spiralis larvae.

M. gastrocnemius. The reduction of muscle larvae calculated at 180 d.p.i. differed according to the dose of infective larvae. The number of larvae was not correlated to the infective doses. The numbers of larvae at 40, 50 and 60 d.p.i. were very similar in each group of rats examined. The rapid decline of larvae was 
observed between days 60 and 120 p.i., and a small reduction was noted until day 180 p.i. (Figs 1, 2, 3). Longer observations would have possibly registered further reduction of larval numbers. However, the subsequent reduction would be very slow as deduced from the characteristics of the curve in the last examinations.

The quantitative changes of T. spiralis in muscles have never been studied in detail. Murrell (1985) demonstated a decline of $T$. spiralis larvae in pigs up to 10 weeks p.i. In man, T. spiralis have been reported to persist for longer period; 24 or even 31 years after infection (Klopsch, 1866; Langerhans, 1892). Rats remain infected for more than two years.

The regulation of larvae number in muscles depends on immune reactions. It is documented by local inflammatory response observed in the close proximity to encysted larvae. The immune cells observed in the infiltrats, around and inside the capsule, are responsible for the larval degradation (Nowoslawski et al., 1969; Neifer et al., 1991; Karmańska et al., 1995, 1997a,b). The immune cells are attracted by larval metabolites secreted through the capsules (Pritchard, 1985). Degradation of larvae by inflammatory cells explains the long-lasting presence of IgM and IgG antibodies as well as circulating antigens (Candolfi et al., 1989).

The results of our experiment are in agreement with the view that trichinellosis in humans does not cause objective symptoms in the late phase, because the larval burden is reduced in the substantial proportion after the $2^{\text {nd }}$ month p.i. According to Kassur et al. (1976), three-four months after infection persisting in muscles larvae no longer present a threat to the host. At this time normalization of indicatory enzymes, such as creatine phosphokinase (Poznańska, 1975) and the other clinical data are noted.

\section{REFERENCES}

Candolfi E., Frache P., Liance M., Houin R. \& Vien T. Detection of circulating antigen in trichinellosis by immunology. Comparative results in mice, rats and humans. Trichinellosis, Proceedings of the $7^{\text {th }}$ International Conference on Trichinellosis, 1989, 194-201.

Karmańska K., Houszka M., Miśta D.\& Stefaniak E. CD 4 and CD8 cells during infection with Trichinella spiralis in mice. Acta Parasitologica, 1995, 40, 53-57.

Karmańska K., houszka M., Widyma A. \& Stefaniak E. The cells observed inside capsuls of larvae in the course of experimental trichinellosis in mice. Wiadomości Parazytologiczne, 1997a, 43, 251-256.

Karmańska K., Houszka M., Widyma A. \& Stefaniak E. Macrophages during infection with Trichinella spiralis in mice. Wiadomości Parazytologiczne, 1997b, 43, 245-249.
Kassur B., Januszkiewicz J. \& Poznańska H. Clinic of trichinellosis, in: Trichinellosis. Kim Ch.W \& Pawlowski Z.S. (eds), University Press of New England, 1976, 27-44.

KLOPSCH. Fall von Trichinen-Erkrankung im Jahre 1842. Volkommene Genesung. Entdeckung eingekapselter lebender Muskeltrichinen 24 Jahre nach der Invasion. Virchows Archiv fur pathologische. Anatomie und Physiologie und fur klinische Medizin, 1866, 35, 609-610.

LANGERHANS R. Ueber regressive Veranderungen der Trichinen und ihrer Kapseln. Virchows Archiv fur pathologische. Anatomie und Physiologie und fur klinische Medizin, 1892, 130, 205-216.

MURRELl K.D. Trichinella spiralis: Acquired immunity in swine. Experimental Parasitology, 1985, 59, 347-354.

Neifer S., Kremsner P.G., Weinig M., Harms G., Sahlmuller G., Bienzle U., Heitman M., Breuer F. \& Mehlhorn H. Interferon-gamma treatment in mice experimentally infected with Trichinella spiralis. Parasitology Reasearch, 1991, 77, 437-442.

Nowoslawski A., Brzosko W.J. \& GANCARZ Z. Immunopathological aspects of experimental trichinellosis. Wiadomości Parazytologiczne, 1969, 15, 642-643.

POZNAŃSKA H. Mathematical interpretation of tissue-serum enzyme activity relation in trichinellosis. Wiadomości Parazytologiczne, 1975, 21, 689-701.

PRITCHARD D.J. Antigen production by encysted muscle larvae of Trichinella spiralis. Journal of Helminthology, 1985, 59, 71-77. 